\title{
Development of Mathematical Learning Media Based on Geogebra Based Learning Problem to Improve Students' Creative Thinking Ability
}

\author{
Raja Maisyarah $^{1^{*}} \quad$ Edi Syahputra $^{2} \quad$ Mulyono $^{2}$ \\ 1.Graduate Program School in Mathematics Education, State University of Medan, \\ Jl. Williem Iskandar Psr. V Medan Estate, 20221, Sumatera Utara, Indonesia \\ 2.Department of Mathematics Education, State University of Medan, Jl. Williem Iskandar Psr. V \\ Medan Estate, 20221, Sumatera Utara, Indonesia
}

\begin{abstract}
This study aims to: 1) find valid, practical and effective mathematics learning media developed with the Geogebraassisted Problem Based Learning model; 2) describe the improvement of mathematical creative thinking ability of class XI students of SMA Negeri 1 Batang Kuis by using mathematics learning media developed with the Geogebra-aided Problem Based Learning model. This type of research is development research (development research) that uses a 4-D development model. This research was conducted through two stages, namely the stage of developing learning media based on Geogebra-assisted Problem Based Learning with Thiagarajan 4-D models, and the stage of testing the learning media of mathematics in class XI MIA 1 and XI MIA 3 SMA Negeri 1 Batang Kuis. From the results of the trial I and trial II obtained valid mathematics learning media according to experts. Based on the results of the analysis of the data obtained shows that the learning media based on Geogebra-assisted Problem Based Learning meets the practical, effective, and can improve mathematical creative thinking abilities. Keywords: Development of Mathematics Learning Media, Problem Based Learning, Geogebra, Mathematical Creative Thinking Ability
\end{abstract}

DOI: $10.7176 / \mathrm{JEP} / 11-2-07$

Publication date: January $31^{\text {st }} 2020$

\section{Introduction}

Learning mathematics is the process of getting the ability to think, reason, communicate, investigate and solve problems (Hidayati and Permana, 2019). The learning process in the 2013 curriculum requires students to actively participate and provide sufficient space for students' creativity, interests, and talents. Technology also became the main focus of the 2013 curriculum (Fitri, Syahputra and Syahputra, 2019).

Entering the Information and Communication Technology Age (ICT) is now very necessary and the importance of the use of ICT (Information and Communications Technology) in learning activities (Tekege, 2017). Through the use of ICTs, we can obtain various information about knowledge, education and other important matters from around the world. In this case, the teacher is expected to be able to utilize ICT in the learning process in the classroom.

The government has designed various efforts to improve the quality of human resources in Indonesia. One step is to develop learning tools that can improve student learning outcomes (Syahputra and Utami, 2019). Therefore, the teacher must be able to create a quality learning process. Using ICT can be done using learning media. Learning media will help the learning process activities in class. Every teacher is required to be able to increase student activity, make teaching and learning activities more effective and provide fun learning by using learning media.

One very important factor in influencing student learning process is the presence of learning media. The presence of instructional media is very helpful for students who are in the concrete operational phase in understanding material that is abstract or unable to be explained in verbal language. The complexity of the material to be conveyed to students can also be simplified with the help of learning media so that students can more quickly understand the subject matter (Batubara, 2017).

The reality on the ground shows that there are still many teachers who have not utilized the learning media. The teacher still uses printed books and lecture methods in the learning process. This is evident from the results of initial observations made at SMA Negeri 1 Batang Kuis. An interview was also conducted with one of the teachers at the school. He said that the facilities and infrastructure available at the school were very adequate, such as the availability of several projectors, laptops, and computer laboratories. The researcher also interviewed a father who served as the person in charge of the computer laboratory said that the laboratory was only used when ICT subjects. Using ICT can be done using learning media. Learning media will help the learning process activities in class. Every teacher is required to be able to increase student activity, make teaching and learning activities more effective and provide a fun learning by using learning media. This means that it has never been used in other subjects, especially in mathematics.

The interview was also conducted with a mathematics subject teacher, Ms. Cut Silvy who stated that the 
learning she did, only used printed books and lecture methods. The teacher has never applied learning media that is in accordance with technological developments. Computers can make abstract concepts concrete with static visualization and dynamic visualization (animation). In addition, computers can make a concept more interesting so that it adds motivation to learn and understand it (Viajayani, et al, 2013). Therefore, assisted by learning media will make students interested in learning.

The results of direct observations made by researchers when the mathematics learning process takes place in class are seen when the teacher teaches, students feel bored so that students look passive and not excited. Students who are taught using the lecture method will make students not understand the material presented by the teacher, because the teacher only conveys material that is still abstract.

The results of the interviews and direct observations can be concluded that the teacher has not been able to develop learning media for mathematics subjects. While the school facilities are sufficient. Teachers tend to only use printed books, which makes students less enthusiastic in learning. The use of media in the learning process in mathematics can be said to have not been maximized.

Problem Based Learning (PBL) is a learning approach that uses real problems as a context for students to learn about critical thinking and problem solving skills, as well as to obtain essential knowledge and concepts from subject matter (Nafiah, 2014). Whereas Selcuk (2010) revealed that PBL in addition to equipping students with knowledge, PBL can also be used to improve problem solving skills, critical and creative thinking skills, lifelong learning, communication skills, group collaboration, adaptation to change and self-evaluation ability. With this model, students will be faced with several problems, then solve them individually / in groups.

To solve these problems, teachers can utilize learning media. So that students feel interested, enthusiastic and active to learn and solve these problems. Arsyad (2011) provides the definition of media as forms of communication both print and audiovisual. Learning media can be a tool to communicate a problem. The use of instructional media is very important in the learning process because it can improve students' understanding of the material so that they can overcome the problems given by the teacher.

Researchers use Geogebra to be used as a learning medium. Geogebra is software with the basic idea of combining geometry, algebra, and calculus which can be used for learning and teaching at elementary, junior high, high school, and university level (Hohenwarter, et al, 2008). Geogebra was developed by Markus Hohenwarter from the University of Florida Atlantic America in 2001. The existence of Geogebra software can help teachers to convey abstract mathematical material to be more easily understood because the software can visualize it, besides this software is made to train students' creativity and critical power (Ekawati, 2016).

The use of media in the process of learning mathematics will help in improving students' mathematical abilities, namely mathematical creative thinking abilities. The ability to think creatively is needed by students to be able to express many ideas and new ideas in solving problems. Mathematical creative thinking ability can be interpreted as the ability to solve mathematical problems with more than one solution (Rahayu, et al, 2019).

Student creativity is one of the factors that influence mathematics learning achievement. Low student creativity is caused by a direct learning process, emphasizing the cognitive aspects of students only, while the affective and psychomotor aspects of students are ignored (Pane, Syahputra and Mulyono, 2017). Nehe, Surya and Syahputra (2017) states that creativity is something that is ignored in learning mathematics. During this time the teacher only teaches about logic and computational ability (counting) so creativity is considered unnecessary in the teaching and learning process in the classroom. Yanti, et al (2019) added that one's creativity is also part of cognitive functions that can help to explain and interpret abstract concepts by involving various skills such as curiosity, ability to find, exploration, search for certainty and enthusiasm.

The low ability to think mathematically creative students can be seen from the answers of students in solving problems. The questions given are in the form of material that has been studied previously. However, only 5 students can do the problem correctly, 8 students still have some errors in the answer process, and other students barely answer the question. Based on the process of student answers stated that students do not understand the purpose of the problem, students can not answer questions more than one way to a mathematical problem, students are less accustomed to thinking about something new in solving a given problem, students have not been able to make detailed ideas in detail, and still using the formula given by the teacher.

To improve students' creative thinking abilities, the teacher's role in managing learning is very important. Most teachers only prioritize results rather than processes, provide knowledge only from the contents of textbooks, use passive teaching methods, and do not use instructional media. With this, the learning process becomes inactive where learning is only centered on the teacher (teacher-oriented), while students only listen to and record the lessons given by the teacher.

In addition, teachers also need to provide exercises at home to improve students' mathematical creative thinking abilities. As stated by Sapta, Hamid and Syahputra (2018) that homework is a very important part of education. Homework has become a necessity and the value has been agreed upon by the government and teachers in schools. This is contained in the syllabus as well as the lesson plans made by the teacher in preparation for teaching. By doing exercises or homework, then we will repeat the subject matter that will strengthen the ability 
to think, especially students' mathematical creative thinking abilities. The aim of the researchers writing this article is to find a valid, practical, effective, and effective medium of mathematics learning that can improve students' mathematical creative thinking abilities by using the Mathematical-aided learning media model of Geogebraassisted learning.

\section{Research Methods}

This research uses the type of Research Development (Research and Development). The development of instructional media that will be carried out in this study is based on the Thiagarajan development model which is also known as the "Four-D Model" or the 4-D model which includes four stages of development, namely: Define, Design, Develop, and Disseminate (Thiagarajan, et al, 1974).

This research was carried out at SMA Negeri 1 Batang Kuis in the odd semester of the Academic Year 2019/2020. The subjects in this study were students of class XI MIA 1 and XI MIA 3 SMA Negeri 1 Batang Kuis, while the object in this study was mathematics learning media with Geogebra-aided Problem Based Learning models on the Circle Equation material.

To assess the quality of a product must meet three criteria, namely validity, practicality, and effectiveness (Nieveen, 2007). So, the mathematics learning media developed by researchers is said to be feasible if the media meets valid, practical and effective criteria. Learning media are said to be valid if they are in the valid minimum category. Product validation can be done by presenting several experts or experienced experts to assess the new product being designed (Sugiyono, 2016).

Table 1. Criteria for Validity Level of Learning Media

\begin{tabular}{|c|c|c|}
\hline No & Va or Total Average Value & Validity Criteria \\
\hline 1 & $1 \leq \mathrm{Va}<2$ & Invalid \\
\hline 2 & $2 \leq \mathrm{Va}<3$ & Invalid \\
\hline 3 & $3 \leq \mathrm{Va}<4$ & Valid enough \\
\hline 4 & $4 \leq \mathrm{Va}<5$ & Valid \\
\hline 5 & $\mathrm{Va}=5$ & Very Valid \\
\hline
\end{tabular}

Akker (2013) states that Practicality refers to the extent that users (and other experts) consider the intervention as clear, usable and cost-effective in 'normal' conditions". The practicality criteria must meet the following limitations: (1) the expert practitioner judges that what is being developed is applicable; and (2) product users find it easy to use products that are developed.

Indicators of learning effectiveness can be based on the achievement of mastery learning (if it has a minimum absorption of $65 \%$, while classical completeness is achieved if $85 \%$ of students have been completed), the achievement of mastery learning objectives (at least $75 \%$ of the learning objectives formulated can be achieved by a minimum of $65 \%$ students), the time spent in learning is efficient or does not exceed normal learning, and students' responses to positive learning (Hasratuddin, 2018).

To determine the level of mastery of students' mathematical creative thinking abilities, the criteria in the following table are used.

Table 2. Mastery Levels of Mathematical Creative Thinking Ability

\begin{tabular}{|c|c|}
\hline Value Interval & Category \\
\hline $0 \leq$ SKBKM $<45$ & Very Less \\
\hline $45 \leq$ SKBKM $<65$ & Less \\
\hline $65 \leq$ SKBKM $<75$ & Enough \\
\hline $75 \leq$ SKBKM $<90$ & Well \\
\hline $90 \leq$ SKBKM $\leq 100$ & Very Good \\
\hline
\end{tabular}

(Sudijono, 2007)

Note: SKBKM is a Mathematical Creative Thinking Ability Score

A class is said to have finished its study if the Classical Completion Percentage (PKK) $\geq 85 \%$. PKK can be calculated by the formula (Trianto, 2011):

$$
P K K=\frac{n}{N} \times 100 \%
$$

Information :

PKK $=$ Percentage of Classical Completeness

$\mathrm{n}=$ Number of students who have finished studying

$\mathrm{N}=$ Number of all students

Student response data were analyzed by calculating the percentage of positive responses for each aspect. The percentage of each positive response is calculated using the formula (Trianto, 2010):

Information:

$$
\text { Percentage of student responses }=\frac{A}{B} \times 100 \%
$$


$A=$ proportion of students who choose

$\mathrm{B}=$ number of students (respondents)

To find out the increase in the ability to think creatively, the data was obtained from the results of the pretest and post-test the ability to think creatively in each trial. The improvement of students' creative thinking skills can be obtained from the normalized gain index data as follows (Lestari and Yudhanegara, 2015):

$$
N-\text { Gain }=\frac{\text { posttest }- \text { pretest }}{\text { ideal score }- \text { pretest }}
$$

Table 3. Normalized Gain Index Criteria (G)

\begin{tabular}{|c|c|}
\hline Gain Score & Category \\
\hline $\mathrm{g}>0.7$ & High \\
\hline $0.3<\mathrm{g} \leq 0.7$ & Medium \\
\hline $\mathrm{g} \leq 0.3$ & Low \\
\hline
\end{tabular}

\section{Results}

\subsection{Description of Learning Media Development Results}

In this development research, the products produced were GeoGebra-assisted learning media, lesson plans (RPP), group worksheets (LKK), and creative thinking skills test instruments. The results of the development of the 4-D model learning media are explained as follows:

\subsubsection{Define}

Based on observations of learning media in SMA Negeri 1 Batang Kuis shows that the use of information and communication technology has not been implemented properly by teachers. The use of instructional media in accordance with technological developments has never been applied by teachers. Teachers are less skilled in developing learning media by utilizing available school facilities. Classroom learning only uses printed books and lecture methods, learning becomes teacher-centered, while students become passive. The lesson plan still does not use a model that can activate students, teachers also do not use worksheets as a support in the learning process. This is the reason that students' mathematical creative thinking ability is still low.

\subsubsection{Design}

At this stage an initial draft of learning media is produced, a lesson plan, a group worksheet for each meeting, a test of students' creative thinking abilities. All results at this design stage are called draft 1 . All of the initial designs are adapted to the Geogebra-assisted Problem Based Learning model so that they become a single entity so that its application is expected to have an impact on increasing the mathematical creative thinking ability of SMA Negeri 1 Batang Kuis students.

\subsubsection{Develop}

After the learning media using the Geogebra-assisted Problem Based Learning model is designed in the form of a draft $\mathrm{I}$, then the validity test is done to the experts/experts and then conducts field trials. The aim is to correct the mistakes and weaknesses of the design results (draft I) which are then used as a basis for revision and refinement of the initial design of learning. Based on the sheet that has been validated by the validator it is found that all the preliminary learning designs developed have met the valid criteria, with a total average value of learning media validation by learning material experts at 4.47 , learning media validation by learning media experts at 4.57 , RPP validation is 4.43 , and Group Worksheet is 4.35 . The students' mathematical creative thinking ability test which has been revised from an expert validator was then trialed to the XII grade students of SMA Negeri 1 Batang Kuis. All items of students' mathematical creative thinking ability test items are declared valid and reliable. After calculation, the reliability test of mathematical creative thinking ability was 0.846 (very high category).

After the learning media developed has met the validity criteria (draft II), then the learning media in the form of draft II was tested at the research site, namely class XI of SMA Negeri 1 Batang Kuis, hereinafter referred to as trial I. Trial I was conducted in class XI MIA 3 with 35 students. Trial I conducted 3 meetings in accordance with the lesson plan (RPP) that had been developed. Trial I was conducted to measure the practicality and effectiveness of learning media (draft II) developed with the Geogebra-assisted Problem Based Learning model which aims to improve students' mathematical creative thinking abilities.

Overall, the results of the analysis of trial I data are that the media developed have met all the practical criteria, but have not yet met the effective criteria set, namely the results of the posttest of students' mathematical creative thinking abilities in a trial I have not met the criteria for achievement of classical completeness. However, an indicator of effectiveness achieved is the achievement of learning time, that is the learning time used during the trial I is the same as ordinary learning. In addition, students respond positively to the learning media developed.

Based on the results of the analysis and trial I, it is necessary to revise the learning media developed in the hope that learning media with Geogebra-assisted Problem Based Learning models can improve students' mathematical creative thinking abilities. The results of the trial I used as a reference to improve the learning media 
developed.

The revised results of trial I produced draft III which will be tested on students of class XI MIA 1, amounting to 36 students. Trial II was conducted 3 times. Trial II was conducted to measure the effectiveness of instructional media (draft III) developed with the Geogebra-assisted Problem Based Learning model which aims to improve students' mathematical creative thinking abilities.

Overall, the results of the analysis of the trial II data are that the learning media developed have been effective, such as the results of the posttest students' mathematical creative thinking abilities in the trial II have met the criteria for achieving classical completeness and the achievement of learning time not exceeding normal learning has been achieved.

Thus, it is known that the results of the second trial are better than the first trial, then based on the results of the second trial it can be concluded that the learning media with the Geogebra-assisted Problem Based Learning model has fulfilled the quality of practical and effective mathematics learning media.

\subsubsection{Disseminate}

The development of learning media has reached the final stage where learning media have received positive assessments from experts and through the development stage. The dissemination phase in this study was carried out in a limited way only to partner schools, namely class XI of SMA Negeri 1 Batang Kuis on the material Equation Circles.

\subsection{Trial Results}

\subsubsection{Trial Results I}

The validity analysis of Geogebra-assisted mathematics learning media developed was seen from 2 aspects, namely the assessment of experts /practitioners of learning media and experts/practitioners of mathematics subjects. The assessment of learning media experts and also learning material experts have been explained previously at the development stage regarding the validation results of the validators, where the results say that the learning media developed was declared valid. For more details, see Table 4.

Table 4. Results of Validation of Learning Media by Experts

\begin{tabular}{|l|c|c|}
\hline \multicolumn{1}{|c|}{ Validator } & Average & Criteria Score \\
\hline Mathematics learning media expert & 4,57 & Valid \\
\hline Expert subject matter in mathematics & 4,47 & Valid \\
\hline
\end{tabular}

Based on the data in Table 4, the interpretation of each media expert and subject matter mathematician is in the valid category.

The teacher's response as a user of learning media has been positive, as well as student responses. However, it still needs to be re-examined and revised so that learning media can be better and more practical.

Description of the Effectiveness of Geogebra Assisted Mathematics Learning Media Developed in Trial 1:

\subsubsection{Classically Completion Results Students Creative Thinking Ability}

The level of mastery of students in terms of the ability to think creatively using the test of creative thinking skills that have been developed. Description of results Students' creative thinking skills in a trial I am shown in Table 5.

Table 5 Classical Mastery Levels of Students' Creative Thinking Ability Test I

\begin{tabular}{|c|c|c|c|c|}
\hline \multirow[b]{2}{*}{ Category } & Pretest & \multirow[b]{2}{*}{$\begin{array}{l}\text { Percentage of thinking } \\
\text { ability }\end{array}$} & Posttest & \multirow[b]{2}{*}{$\begin{array}{l}\text { Percentage of thinking } \\
\text { ability }\end{array}$} \\
\hline & $\begin{array}{c}\text { Total } \\
\text { students }\end{array}$ & & $\begin{array}{c}\text { Total } \\
\text { students }\end{array}$ & \\
\hline Complete & 22 & $62,86 \%$ & 27 & $75 \%$ \\
\hline Not Complete & 13 & $37,14 \%$ & 8 & $25 \%$ \\
\hline Total & 35 & $100 \%$ & 35 & $100 \%$ \\
\hline Average & 69,97 & & 78,08 & \\
\hline
\end{tabular}

For more details can be seen in the following diagram picture:

\section{Trial I}

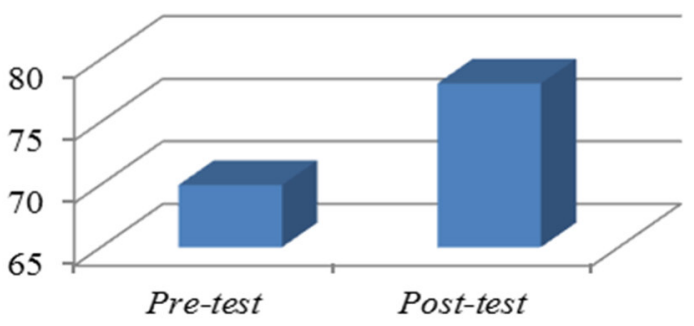

Figure 1. Average Value in Trial I

Based on the diagram above, it was found that the average value of students 'mathematical creative thinking 
abilities in the pretest I trial was 69.97 while the average value of students' mathematical creative thinking abilities at the posttest was 78.08 .

\subsubsection{Achievement of Learning Objectives}

The achievement of the posttest learning objectives mathematical creative thinking abilities in the first try can be seen in the following table.

Table 6. Achievement of Learning Objectives towards Mathematical Creative Thinking Ability in Trial I

\begin{tabular}{|c|c|c|c|}
\hline \multirow[b]{2}{*}{ No } & \multirow[b]{2}{*}{ Learning objectives } & \multicolumn{2}{|c|}{ Creative thinking ability } \\
\hline & & $\begin{array}{l}\% \text { achievement of } \\
\text { learning objectives }\end{array}$ & Information \\
\hline 1. & $\begin{array}{l}\text { Find the concept of a circle equation with a center point at } \\
\mathrm{P}(0,0) \text { or in } \mathrm{P}(\mathrm{a}, \mathrm{b}) \text { through authentic problem solving. }\end{array}$ & $81,04 \%$ & Reached \\
\hline 2. & $\begin{array}{l}\text { Find common shapes of circle equations through authentic } \\
\text { problem solving. }\end{array}$ & $82,14 \%$ & Reached \\
\hline 3. & $\begin{array}{l}\text { Analyze the position of a oint with respect to a circle centered at } \\
\mathrm{P}(0,0) \text { or at } \mathrm{P}(\mathrm{a}, \mathrm{b}) \text {. }\end{array}$ & $78,82 \%$ & Reached \\
\hline 4. & Describe the circle of the problem given. & $70,31 \%$ & $\begin{array}{c}\text { Not } \\
\text { achieved }\end{array}$ \\
\hline
\end{tabular}

Thus, the achievement of learning objectives in trial I have not yet been achieved in point four.

\subsubsection{Trial Learning Time Achievement I}

Based on research conducted in trial I in class XI MIA 3 SMA Negeri 1 Batang Kuis, the use of time to teach circle equation material using Geogebra-assisted media is in accordance with the learning implementation plan made by researchers, namely the learning time carried out is the same as learning time as usual, so it can be said that research using Geogebra-assisted mathematics learning media that has been developed has a good time achievement.

Increased mathematical creative thinking ability in the first trial will be seen through the N-Gain from the results of the pretest and posttest mathematical creative thinking abilities in the first trial.

Table 7. N-Gain Results for The Mathematical

Creative Thinking Ability Test I

\begin{tabular}{|c|c|c|}
\hline N-Gain & Interpretation & Number of Students \\
\hline $\mathrm{g}>0.7$ & High & 5 \\
\hline $0.3<\mathrm{g} \leq 0.7$ & Medium & 22 \\
\hline $\mathrm{g} \leq 0.3$ & Low & 8 \\
\hline
\end{tabular}

Based on Table 7 it can be seen that 5 students got an N-Gain score in the "High" category. For students who have mathematical creative thinking abilities with the category "Medium" as many as 22 students and 8 other students get N-Gain scores with the "Low" category.

\subsubsection{Trial Results II}

\subsubsection{Classically Completion Results Students Creative Thinking Ability}

The level of mastery of students in terms of the ability to think creatively using the test of creative thinking skills that have been developed. A description of the results of students' creative thinking abilities in trial II is shown in the following table.

Table 8. Classical Mastery Levels of Students' Creative Thinking Ability Test II

\begin{tabular}{|c|c|c|c|c|}
\hline \multirow[b]{2}{*}{ Category } & Pretest & \multirow[b]{2}{*}{$\begin{array}{l}\text { Percentage of thinking } \\
\text { ability }\end{array}$} & Posttest & \multirow[b]{2}{*}{$\begin{array}{l}\text { Percentage of thinking } \\
\text { ability }\end{array}$} \\
\hline & $\begin{array}{c}\text { Total } \\
\text { students }\end{array}$ & & $\begin{array}{c}\text { Total } \\
\text { students }\end{array}$ & \\
\hline Complete & 20 & $55,56 \%$ & 32 & $88,89 \%$ \\
\hline Not Complete & 16 & $44,44 \%$ & 4 & $11,11 \%$ \\
\hline Total & 36 & $100 \%$ & 36 & $100 \%$ \\
\hline Average & 71,44 & & 83,81 & \\
\hline
\end{tabular}

For more details can be seen in the following diagram picture: 


\section{Trial II}

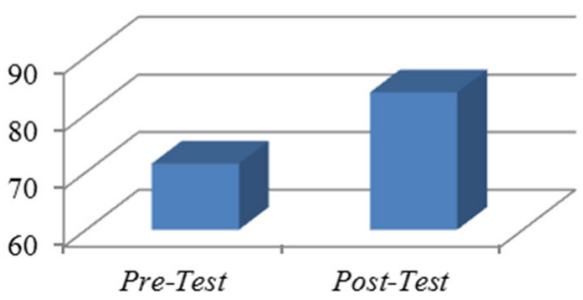

Figure 2. Average Value In Trial II

Based on the diagram above, it was found that the average value of students 'mathematical creative thinking abilities in the pretest II trial was 71.44 while the average value of students' mathematical creative thinking abilities at the posttest was 83.81 .

From Table 8 it can be seen that the classical mastery results of students 'creative thinking abilities in the pretest II try out were $55.56 \%$ while the classical mastery results in the students' creative thinking abilities in the posttest II were $88.89 \%$. In accordance with the criteria of mastery learning students classically, which is at least $85 \%$ of students who take the test of the ability to think creatively classically. So it can be concluded that in the second trial Geogebra-assisted mathematics learning media developed met classical completeness criteria.

\subsubsection{Achievement of Learning Objectives}

The achievement of the posttest learning objectives mathematical creative thinking abilities in the second trial can be seen in the following table.

Table 9. Achievement of Learning Objectives for Mathematical

Creative Thinking Ability in Trials II

\begin{tabular}{|l|l|c|c|}
\hline \multirow{2}{*}{ No } & \multicolumn{1}{|c|}{ Learning objectives } & \multicolumn{2}{|c|}{ Creative thinking ability } \\
\cline { 3 - 4 } & \multicolumn{1}{|c|}{$\begin{array}{c}\text { \% achievement of } \\
\text { learning objectives }\end{array}$} & Information \\
\hline 1. & $\begin{array}{l}\text { Find the concept of a circle equation with a center point at } \\
\mathrm{P}(0,0) \text { or in } \mathrm{P}(\mathrm{a}, \mathrm{b}) \text { through authentic problem solving. }\end{array}$ & $88,54 \%$ & Reached \\
\hline 2. & $\begin{array}{l}\text { Find common shapes of circle equations through authentic } \\
\text { problem solving. }\end{array}$ & $86,81 \%$ & Reached \\
\hline 3. & $\begin{array}{l}\text { Analyze the position of a oint with respect to a circle centered at } \\
\text { P(0,0) or at } \mathrm{P}(\mathrm{a}, \mathrm{b}) .\end{array}$ & $86,46 \%$ & Reached \\
\hline 4. & Describe the circle of the problem given. & $84,20 \%$ & Reached \\
\hline
\end{tabular}

In accordance with the criteria for achievement of learning objectives, it is said that learning objectives are achieved with a criterion of $\geq 75 \%$ of the maximum score of 4 (four) points. Thus the achievement of learning objectives in Trial II namely on the results of the students' mathematical creative thinking ability postest has been achieved.

\subsubsection{Trial Learning Time Achievement II}

This is in accordance with the criteria of learning time, namely the achievement of minimum learning time is the same as regular learning, thus the achievement of learning time for trial II has been achieved.

Increased creative thinking skills in the second trial will be seen through the N-Gain from the results of the pretest and posttest mathematical creative thinking abilities in the second trial.

Table 10. N-Gain Results for The Mathematical

Creative Thinking Ability Test II

\begin{tabular}{|c|c|c|}
\hline N-Gain & Interpretation & Number of Students \\
\hline $\mathrm{g}>0.7$ & High & 18 \\
\hline $0.3<\mathrm{g} \leq 0.7$ & Medium & 18 \\
\hline $\mathrm{g} \leq 0.3$ & Low & 0 \\
\hline
\end{tabular}

Based on Table 6 it can be seen that 18 students received an N-Gain score in the "High" category. For students who received an N-Gain score in the "Medium" category were 18 students.

\section{Discussion}

Based on the analysis results in trials I and II it was found that the students' creative thinking abilities had met the classical completeness criteria. This is caused by the material and problems that exist in the mathematics learning media developed from group worksheets in accordance with real problems in life. By using instructional media in the classroom, students will better understand the concept of circle equations. This is supported by Japa, Suarjana and Widiana (2017) which state that the media system is an implementation of learning that utilizes technology and is not limited by space and time. The existence of Information and Communication Technology can provide 
new nuances to encourage a better process of learning mathematics. This is in line with research of Rasyid, Azis, and Saleh (2016) which also reveal that instructional media can represent what teachers are less able to say through words. The abstractness of the material can be concretized with the presence of learning media. The students' mathematical creative thinking ability can be improved because GeoGebra-assisted learning media is applied to students who have met the criteria for good quality learning media, learning media is also easy to use and uses Geogebra-aided Problem Based Learning models in the learning process.

As mentioned in the research of Sari, Hidayati, and Wahyuni (2019) state that the creative thinking abilities of students who are taught using learning media are better than students who are taught without using learning media. The same thing was expressed by Fahmi and Priwantoro (2017) which state that learning using media can improve students' creative thinking abilities. In line with this research, the results of the study Sudiantini and Shinta (2018) state that using instructional media can improve students' creative thinking abilities at school. This means that using learning media when the teaching and learning process takes place can improve students' creative thinking abilities. Based on the results of the research that has been done also based on the results of relevant previous studies, it can be concluded that the Geogebra-assisted mathematics learning media developed has a positive impact on students' creative thinking abilities.

\section{Conclusions}

Based on the results of research and discussion, the following conclusions are obtained: 1) learning media using the Geogebra-assisted Problem Based Learning model that has been developed has met the criteria of valid, practical and effective. 2) The learning media can also improve the mathematical creative thinking ability of class XI students of SMA Negeri 1 Batang Kuis.

\section{Acknowledgment}

On this occasion the authors would like to express their sincere thanks and highest appreciation to all those who have helped the author: Mr. Prof. Dr. Edi Syahputra, M.Pd as the supervisor I and Chair of the Mathematics Education Postgraduate Study Program, Mr. Dr. Mulyono, M.Si as the supervisor II and Secretary of the Mathematics Education Postgraduate Program Study Program, Mr. Adi Sumarno, S.Pd as the Principal of the Batang Kuis 1 High School who has given permission and the opportunity for the author to conduct research in the school he is leading, and teachers and administrative staff who have helped many writers in conducting this research.

\section{References}

Akker, J., V., A. (2013). (Ed.) Educational Design Reseach. The Netherlands: SLO Enschede. Arsyad, A. (2011). Learning Media. Jakarta: PT. Raja Grasindo Persada.

Batubara, H. H. (2017). Development of Android-Based Mathematics Learning Media for Elementary / MI Students, MUALLIMUNA: Journal of Madrasah Ibtidaiyah, 3(1):12-27

Ekawati, A. (2016). Use of Geogebra and Microsoft Mathematics Software in Mathematics Learning. Math Didactic: Journal of Mathematics Education, 2(3):148-153.

Fahmi, S., \& Priwantoro, S. W. (2017). Assistance in Making E-Learning with Moodle Integrated with Geogebra Mathematics Software for Mathematics Teachers in Muhammadiyah Junior High Schools in Godean District, Sleman, Yogyakarta. Axiology: Journal of Community Service, 1(2):135-141.

Fitri, S., Syahputra, E., \& Syahputra, H. (2019). Blended Learning Rotation Model of Cognitive Conflict Strategy to Improve Mathematical Resilience in High School Students. International Journal of Scientific \& Technology Research, 1(1).

Hake. (1999). Analyzing Change/ Gain Scores, Woodland Hilis: Dept. of Physics, Indiana University.

Hasratuddin. (2018). Why Must Study Mathematics, Medan: Perc. Edira.

Hidayati, N. \& Permana, D. (2019). Assessment of Problem Solving Abilities and Student Learning Activities Based On Learning Tools: The Basis of Problem Based Learning Development. International Journal of Scientific \& Technology Research, 8(11): 453-456.

Hohenwarter, M., Hohenwarter, J., Kreis, Y. \& Lavicza, Z. (2008). Teaching and Learning Calculus with Geogebra's free dynamic mathematics software. (Online). Available: http://www.geogebra.org/publications/2008-ICME-TSG16-CalculusGeoGebra-Paper.pdf. [November 9, 2018].

Japa, N., Suarjana \& Widiana. (2017). Geogebra Media in Mathematics Learning. International Journal of Natural Science and Engineering, 1(2):40-47.

Lestari, K.E., and Yudhanegara, M. R. (2015). Mathematics Education Research, Bandung: Refika Aditama.

Nafiah, Y.N. (2014). Application of Problem Based Learning Models to Improve Critical Thinking Skills and Student Learning Outcomes. Journal of Vocational Education, 4(1): 125-143.

Nehe, M., Surya, E., \& Syahputra, E. (2017). Creative Thinking Ability to Solving Equation and Non-Equations 
of Linear Single Variables in VII Grade Junior High Schools. International Journal of Advance Research And Innovative Ideas In Education (IJARIIE), 3(2):2146-2152.

Nieveen. (2007). An Introduction to Educational Design Research. Proceedings of the Seminar Conducted at The East China Normal University, Shanghai (PR China).

Pane, N., Syahputra, E., \& Mulyono. (2017). Model-Eliciting Activities Approach as a Tool to Improve Creative Thinking Skills and Self-Confidence. Advances in Social Science, Education and Humanities Research, vol.104.

Rahayu, EL, Akbar, P., \& Afrilianto, M. (2019). The Effect of the Mind Mapping Method on Thinking Aloud Pair Problem Solving Strategies on Mathematical Creative Thinking Abilities. Journal On Education, 1(2): 271278.

Rasyid, M., Azis, A. A., \& Saleh, A. R. (2016). Development of Multimedia-Based Learning Media in Sense System Concepts in Class XI High School Students. Journal of Biology Education, 7(2):69-80.

Sari, S. L., Hidayati, D. W., \& Wahyuni, A. (2019). The Application of Geogebra Assisted Brain-Based Learning Strategies to Students' Creative Thinking Abilities. Square: Journal of Mathematics and Mathematics Education, 1(1):13-18.

Sapta, A., Hamid, A., \& Syahputra, E. (2018). Assistance of Parents In The Learning At Home. IOP Conf. Series: Journal of Physics: Conf. Series 1114 (2018) 012020 DOI: 10.1088 / 1742-6596 / 1114/1/012020.

Selcuk, G. S. (2010). The Effects of Problem-Based Learning on Pre-service Teachers' Achievements, Approaches and Attitudes Towards Learning Physics. International Journal of Physical Sciences, 5(6):711-723.

Sinaga, B. (2007). Development of Mathematical Learning Models Based on Problems Based on Batak Culture (PBM-B3). Dissertation. Surabaya State University Graduate Program.

Sudiantini, D., \& Shinta, N. D. (2018). Effects of Learning Media on Creative Thinking Ability and Students' Mathematical Reasoning. Journal of Education and Community Empowerment, 11(1):177-186.

Sudijono, A. (2007). Introduction to Educational Evaluation, Jakarta: Raja Grafindo Persada.

Syahputra, E., \& Utami. D. R. (2019). The design of the IQF-oriented ARCS-based learning model. International Seminar on Applied Mathematics and Mathematics Education. IOP Conf. Series: Journal of Physics: Conf. Series 1315 (2019) 012065, 2019, DOI: 10.1088 / 1742-6596 / 1315/1/012065.

Sugiyono. (2016). Educational Research Methods (Quantitative, Qualitative and R\&D Approaches). Bandung: Alfabeta.

Tekege, M. (2017). Utilization of Information and Communication Technology in High School YPPGI Nabire Learning. Fateksa Journal: Journal of Technology and Engineering, 2(1).

Thiagarajan, S., Semmel, D., \& Semmel, M. (1974). Instructional Development for Training Teachers of Exceptional Children. Indiana: Indiana University Bloomington.

Trianto. (2011). Designing Innovative-Progressive Learning Models: Concepts, Foundations and Their Implementation in the Education Unit Level Curriculum (KTSP)", Jakarta: PT Kencana Prenada Media Group.

Trianto. (2010). Integrated Learning Models: Concepts, Strategies, and Their Implementation in the Education Unit Level Curriculum (KTSP), Jakarta: PT Bumi Aksara.

Viajayani, ER, Radiyono, Y., \& Rahardjo, DT. (2013). Development of Physics Learning Media Using Macromedia Flash Pro 8 on the subject of Temperature and Heat. Journal of Physics Education, 1(1): 144155.

Yanti, F. A., Kuswanto, H., Mundilarto, Jumadi, \& Rosa, F. O. (2019). Development of Analog Material Based Physics Module to Improve Concept Understanding and Creative Thinking. International Journal of Scientific \& Technology Research, 8(10):1244-1248. 